\title{
Didatic approach of ultrasonographic examination for evaluation of the carpal joint in horses
}

\author{
Maria Cristina Ferrarini Nunes Soares Hage ${ }^{1^{*}}$ Mariana Sachi Invernizzi $^{1}$ \\ Gabriela Monaldo Corrá Bellegard ${ }^{1}$ Renata Gebara Sampaio Dória ${ }^{1}$ \\ Silke Verena Schwarzbach ${ }^{1}$ Vanessa Junko Yamaguti Miada ${ }^{1}$
}

${ }^{1}$ Departamento de Medicina Veterinária, Faculdade de Zootecnia e Engenharia de Alimentos (FZEA), Universidade de São Paulo (USP), 13635-900, Pirassununga, SP, Brasil. E-mail: crishage@usp.br. *Corresponding author.

\begin{abstract}
The carpus is a complex articulation, which is often involved in injuries in equine athletes. The objective of this study was to suggest a didactic approach for ultrasonography training for the examination of the carpal joint in horses. Ultrasonograhy examination was performed in a healthy 14-year-old horse. The images were compared with those of a dissected anatomic specimen of the carpal region of a senior horse and with those reported in the literature. Identifiable structures were as follows: (dorsal) tendon of the muscle extensor carpi radialis, tendon of the muscle extensor carpi obliquus, tendon of the muscle commom digital extensor, dorsal synovial outpouchings, joint capsule and fat cushion, (lateral) tendon of the muscle lateral digital extensor, lateral collateral ligament (deep and superficial components), (medial) medial collateral ligament (deep and superficial components) and (palmar) palmar intercarpal ligament, carpal sheath, carpal tunnel, superficial digital flexor tendon, proximal origin of the deep digital flexor tendon, and palmar carpal ligament. Prior knowledge of the anatomy in combination with the study of anatomical specimens is essential for recognizing musculoskeletal structures during ultrasound examination, contributing to the training and learning processes.
\end{abstract}

Key words: horses, education, bones, tendons, ultrasonography.

\section{Abordagem didática do exame ultrassonográfico} da articulação do carpo em equinos

RESUMO: $O$ carpo é uma articulação complexa que, com frequência, é sede das doenças que acometem cavalos atletas. O objetivo deste estudo foi sugerir uma abordagem didática para o treinamento de exame ultrassonográfico do carpo em equinos. Foi realizado o exame ultrassonográfico de um equino hígido de catorze anos, as imagens foram comparadas com uma peça anatômica dissecada da mesma região de um cadáver de equino sênior e com dados da literatura. As estruturas passíveis de identificação foram: (dorsal) tendão do músculo extensor carporradial, tendão do músculo extensor obliquo do carpo, tendão do músculo extensor digital comum, recessos sinoviais dorsais, cápsula articular, coxim de gordura, (lateral) tendão do músculo extensor digital lateral, ligamento colateral lateral (componente profundo e superficial), (medial) ligamento colateral medial (componente profundo e superficial), (palmar) ligamento intercarpiano palmar, bainha carpal, canal carpal, tendão do músculo flexor digital superficial, origem proximal do tendão do músculo flexor digital profundo e o ligamento carpal palmar. $O$ conhecimento prévio da anatomia associada ao estudo em peças anatômicas são elementos essenciais para o reconhecimento das estruturas musculoesqueléticas ao ultrassom, contribuindo para o treinamento e processo de aprendizagem.

Palavras-chave: cavalos, ensino, ossos, tendões, ultrassom.

Carpal diseases are common in equine athletes because sports activities generate increased biomechanical forces in this region during exercises (WASELAU et al., 2006).

Technological advances have provided significant advantages in the diagnosis of various alterations in equine limbs (GARVICAN \& CLEGG, 2007). Despite the variety of diagnostic imaging techniques available, ultrasonography is the ideal modality for evaluating the soft tissue in this region. It is the most cost-effective imaging modality to diagnose soft tissue injuries and can be performed by motivated practioners with basic ultrasonography skills and equipment. Knowledge of the normal ultrasound appearance of anatomic structures is essential to conduct proper ultrasonographic examinations (DENOIX, 2009). Some indications for carpal ultrasonography are painful carpus joint; joint 
swelling to check for synovial effusion and thickening of the joint capsule; inconclusive radiographic evaluation, pre-surgical carpal planning; quick assessment in the field; previous treatment failure; and to evaluate the thickness of articular cartilage in foals (incomplete ossification) (REEDING, 2001a; REEDING, 2001b). Reef (1998) indicated carpal ultrasonography for avulsion fractures and ruptures of the medial colateral ligament.

The aim of the present study was to suggest a didactic approach to the training of equine carpus ultrasonography for veterinary medicine students, residents, and professionals.

The study was conducted in a healthy 14-year-old mixed-breed equine. The region of interest was shaved with a blade with care to not injury the horse. Then, ultrasonography coupling gel, sometimes alcohol, was applied. Ultrasonographic examination was performed using a My Lab 30 Vet Gold device with the linear frequency transducer set at $6-18 \mathrm{MHz}$ and without the use of a standoff pad. Longitudinal and transverse planes from dorsal, lateral, medial and palmar surfaces of the carpal joint were examined. The dissected anatomical specimen of this region from a cadaver of a horse was analyzed for comparison.

DORSAL SURFACE: The tendon of the muscle extensor carpi radialis (TMECR) was located at the distal end of the radius bone in the dorsolateral region of the carpal joint, distally extending along the dorsal metacarpus surface. As described by REDDING (2001a), fibers appeared as uniform and parallel echogenic structures in the longitudinal plane and as circular structures in the transverse plane. A small amount of anechogenic liquid was reported in the tendon sheath region, as described by REEF et al. (2004a).

Thenormal musculature was heterogeneous in appearance, with striated and hypoechogenic features, which were also reported in the studies by REEF et al. (2004b). The tendon of the muscle extensor carpi obliquus (TMECO) was superficially located at the TMECR. Tendon of the muscle commom digital extensor (TMCDE) overlapped the distal radius and dorsal carpus, extending to the proximal metacarpal region.

The joint capsule (JC) was observed in the distal radius and the proximal row of carpal bones, and was characterized as an anechogenic layer over the bone, in accordance with the findings of REEF et al. (2004a). A fat cushion (FC) can be observed dorsally to the joint capsule of the radiocarpal joint, in longitudinal images; it is hypoechogenic and triangular in shape. The dorsal synovial outpouchings (DSO) of the radiocarpal and middle carpal joints are seen as virtual spaces without ecos.

LATERAL SURFACE: The tendon of the muscle lateral digital extensor (TMLDE) was seen in the lateral region of the distal radius. The lateral collateral ligament extends from the lateral (ulnar) styloid process distally to the third and fourth metacarpal bones. Both the lateral collateral ligament superficial component (LCLS; long and superficial) and the lateral collateral ligament deep component (LCLD; short and deep) were reported. The LCLD extends from palmar to the dorsal, while the LCLS extends from a dorsal to a palmar direction (Reef, 1998). Its ultrasound appearance was echogenic with thin parallel lines that may exhibit discrete echogenicity variations, similar to the descriptions by REDDING (2001a) and DENOIX (2009).

MEDIAL SURFACE: The medial collateral ligament has two components that must be ultrasonographically imaged in separate planes. The deep component (LCMD) should be examined longitudinally and slightly obliquely, with the proximal portion of the transducer angled dorsally. The superficial component (LCMS) should be examined longitudinally and slightly oblique, with the transducer angled palmarly.

PALMAR SURFACE: In the palmar region, with the carpus flexed and the transducer positioned transversely, the palmar intercarpal ligament (PIL) is observed superficially and just below the skin. With the limb supported dorsally to the PIL, we observed the superficial flexor tendon (SDFT) and the proximal origin of the deep digital flexor tendon (PODDFT), surrounded by the carpal sheath (CS), in the carpal tunnel (CT), both in cross-sectional and longitudinal sections, where muscle bundles could be observed. The palmar carpal ligament (PCL) is a thick, dense estruture that firmly attaches to the carpal bones and forms the dorsal wall of the CT (REEF, 1998).

Extensor retinaculum, a fascia that holds the tendons of the carpal extensor muscles was observed in the distal row of the carpal bones. On ultrasonographic examination, it appeared as a hyperechogenic interface, similar to the description of the flexor retinaculum by SHIELDS et al. (2015). Cortical regions of radius, radial carpus, intermediate carpus, third carpal, ulnar carpus, fourth carpal, and accessory carpus bones were seen as a hyperechogenic line with intense acoustic shadowing, which is in accordance with the findings of REEF et al. (2004b). Figures 1, 2, 3 and 4 show the structures described above.

In conclusion, dissection of the structures provided a better understanding of the anatomy to be 

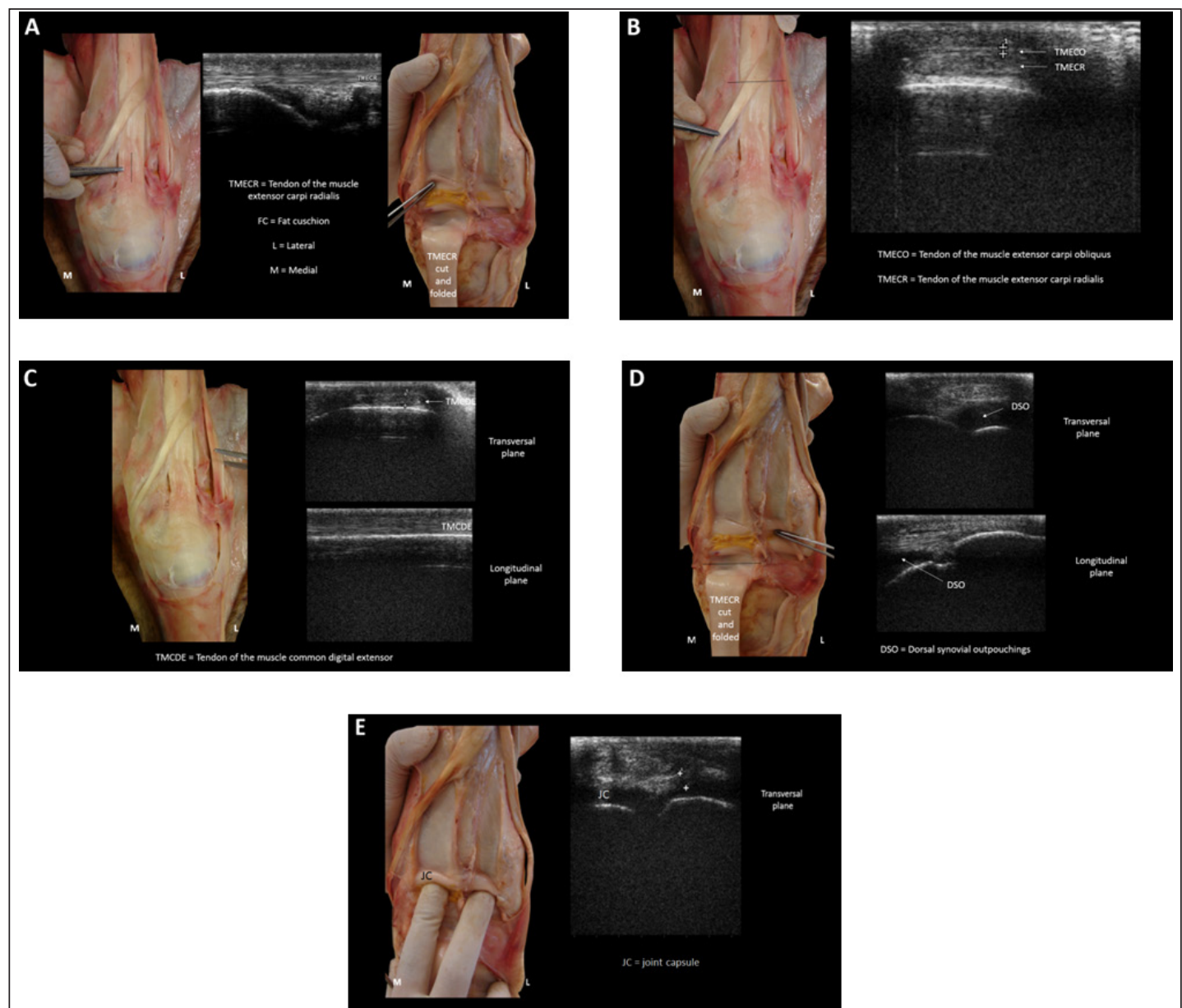

Figure $1(\mathrm{~A}, \mathrm{~B}, \mathrm{C}, \mathrm{D}, \mathrm{E})$ - Dorsal carpus: TMECR $=$ tendon of the muscle extensor carp1 radialis, $\mathrm{FC}=$ fat cushion, TMECO $=$ tendon of the muscle extensor carpi obliquus, $\mathrm{TMCDE}=$ tendon of the muscle common digital extensor, $\mathrm{DSO}=$ dorsal synovial outpouchings, $\mathrm{JC}=$ joint capsule. $\mathrm{L}=$ lateral, $\mathrm{M}=$ medial.

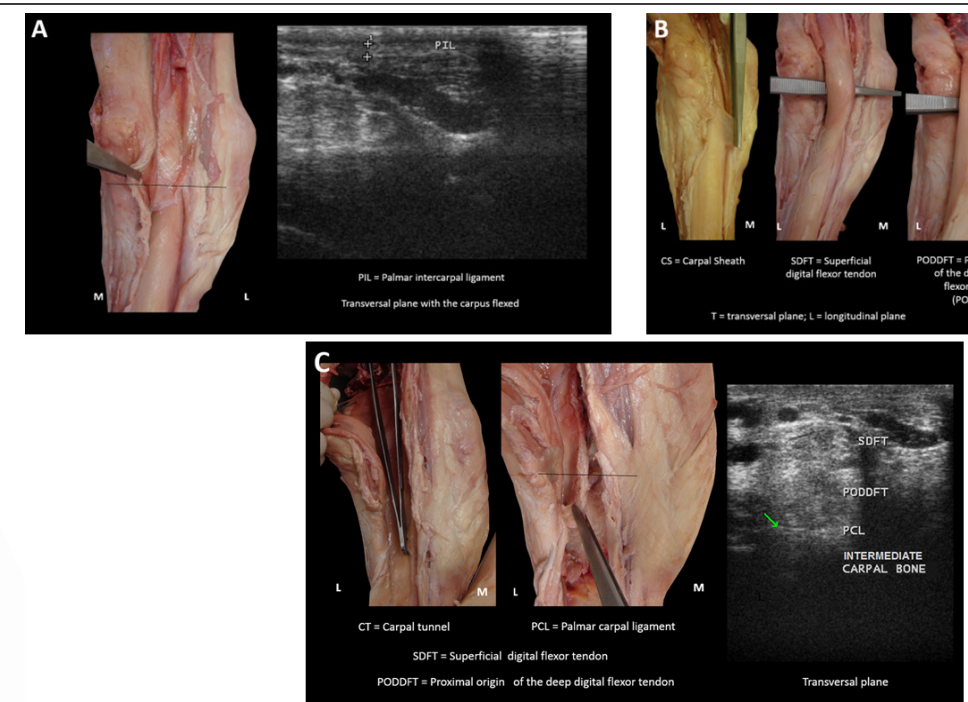

Figure $2(\mathrm{~A}, \mathrm{~B}, \mathrm{C})$ - Lateral carpus: TMLDE = tendon of the muscle lateral digital extensor, $\mathrm{LCLS}=$ lateral collateral ligament, superficial component, LCLD = lateral collateral ligament, deep component. $\mathrm{D}=$ dorsal, $\mathrm{P}=$ palmar. 

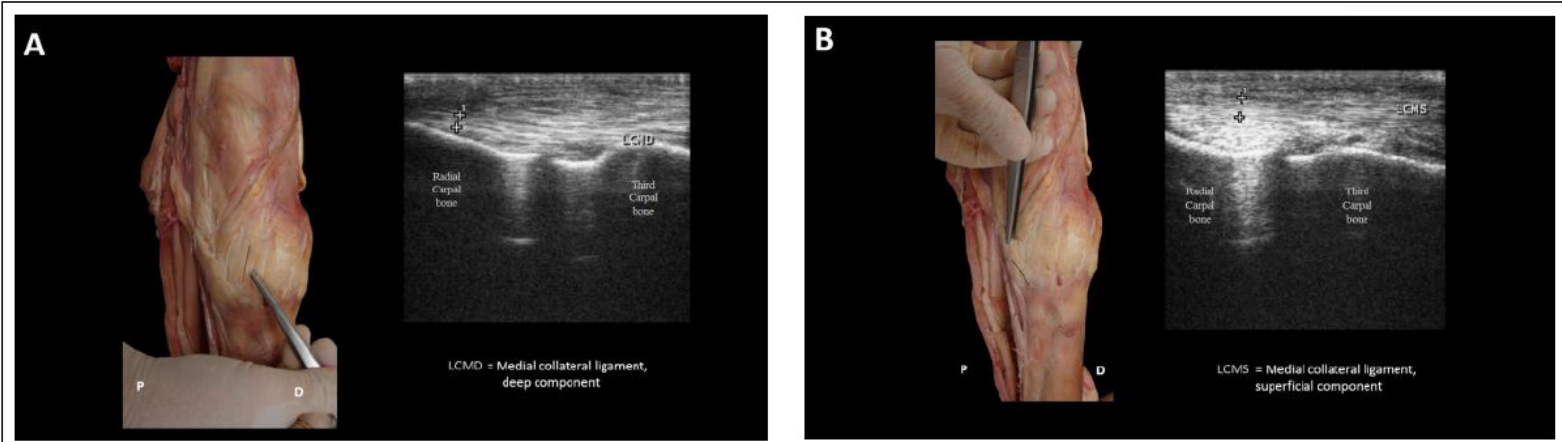

Figure $3(\mathrm{~A}, \mathrm{~B})$ - Medial carpus: LCMD = medial collateral ligament, deep component, radial carpal bone, third carpal bone, LCMS = medial collateral ligament, superficial component. $\mathrm{D}=$ dorsal, $\mathrm{P}=$ palmar.
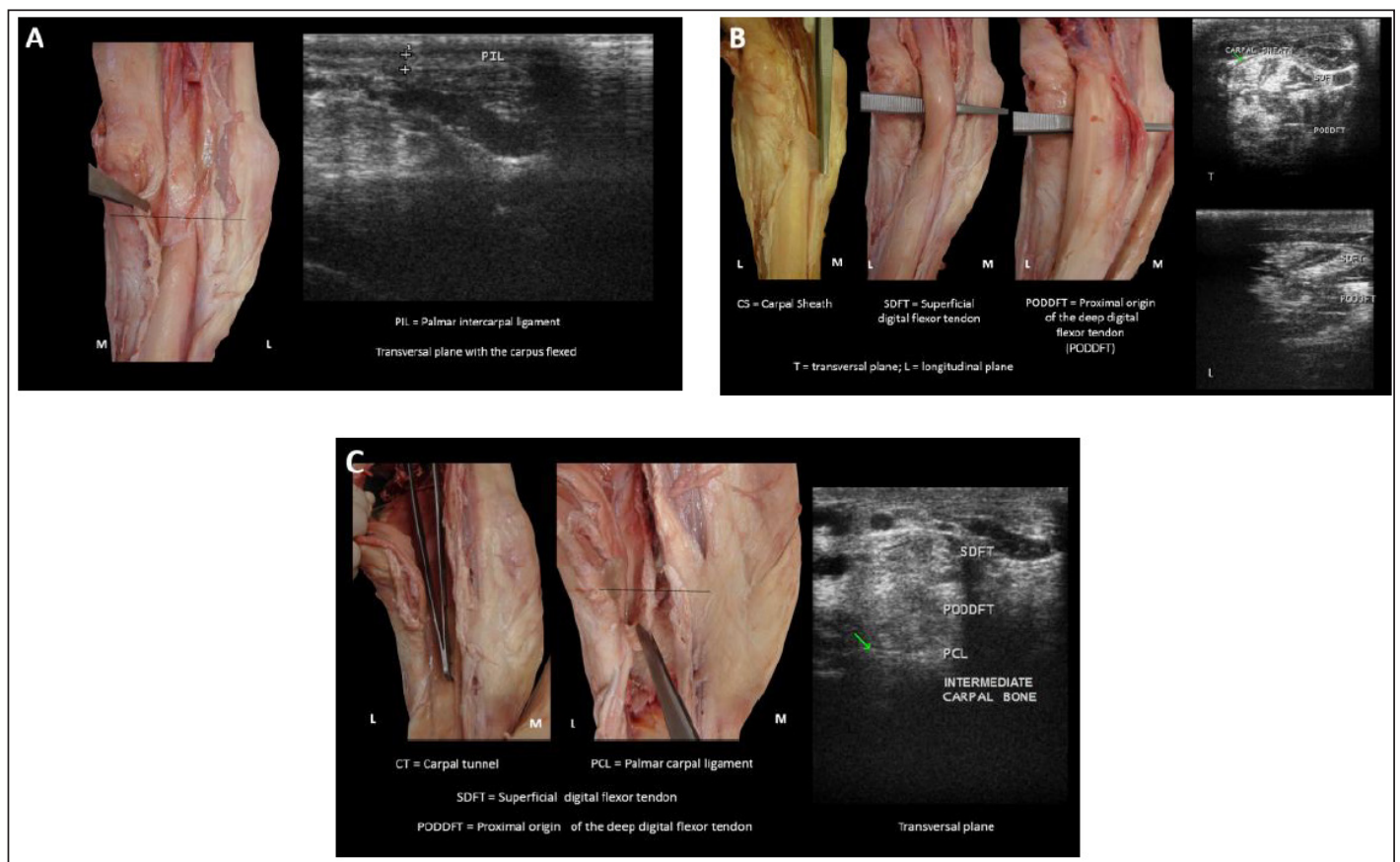

Figure 4 (A, B, C) - Palmar carpus: PIL = palmar intercarpal ligament, $\mathrm{CS}=$ carpal sheath, SDFT $=$ superficial digital flexor tendon, PODDFT $=$ proximal origin of the deep digital flexor tendon, $\mathrm{CT}=$ carpal tunel, $\mathrm{PCL}=$ palmar carpal ligament, intermediate carpal bone. $\mathrm{L}=$ lateral, $\mathrm{M}=$ medial.

examined during the ultrasound examination. This approach allowed the creation of an examination protocol for this anatomical region. In addition, continuous practice of ultrasonographic examinations in healthy animals facilitates the immediate identification of alterations.

\section{REFERENCES}

DENOIX, J.M. Ultrasonographic examination of joints, a revolution in equine locomotor pathology. Bulletin de l'Académie Véterinarie de France, v.162, n.4/5, p.313-325, 2009. Available from: <http://hdl.handle.net/2042/48009>. Accessed: Oct. 02, 2016. doi: $10.4267 / 2042 / 48009$.

GARVICAN, E.; CLEGG, P. Clinical aspects of the equine carpal joints. Companion Animal, v.12, n.1, p.15, 2007. Available from: <http://onlinelibrary.wiley.com/ doi/10.1111/j.2044-3862.2007.tb00109.x/abstract>. Accessed: Sept. 27, 2016. doi: 10.1111/j.2044-3862.2007.tb00109.x.

REDDING, W.R. Use of ultrasonography in the evaluation of joint disease in horses. Part 1: indications, technique and examination of the soft tissues. Equine Veterinary Education, v.13, n.4. p.198-204, 2001a. Available from: $<$ http://onlinelibrary.wiley.com/doi/10.1111/j.2042-3292.2001. 
tb00090.x/abstract>. Accessed: Sept. 02, 2016. doi: 0.1111/ j.2042-3292.2001.tb00090.x.

REDDING, W.R. Use of ultrasonography in the evaluation of joint disease in horses. Part 2: examination of the articular surface. Equine Veterinary Education, v.13, n.5, p.275280, 2001b. Available from: <http://onlinelibrary.wiley.com/ doi/10.1111/j.2042-3292.2001.tb00108.x/epdf>. Accessed: May 12, 2017. doi: 10.1111/j.2042-3292.2001.tb00108.x.

REEF, V.B. Equine diagnostic ultrasound. Philadelphia: Saunders, 1998. 560p.

REEF, V.B. et al. Joint ultrasonography. Clinical Techniques in Equine Practice, v.3. p.256-267, 2004a. Available from: $<$ http://dx.doi.org/10.1053/j.ctep.2005.02.003>. Accessed: Oct. 12,2016
REEF, V.B. et al. Muscle and bone. Clinical Techniques in Equine Practice, v.3. p.268-273, 2004b. Available from: <http:// dx.doi.org/10.1053/j.ctep.2005.02.004>. Accessed: Oct. 12, 2016.

SHIELDS, G.E. et al. How to ultrasound the carpal canal and caudal antebrachium. American Association of Equine Practitioners, v.61, p.439-447, 2015. Available from: $<$ http://files. eventsential.org/b6a3b65a-f39c-4146-ae3a-c5737f59fefb/event576/91393873-Shields\%20-\%20How\%20to\%20Ultrasound.pdf>. Accessed: Oct. 12, 2016.

WASELAU, M. et al. Computed tomographic documentation of a comminuted fourth carpal bone fractures associated with carpal instability treated by partial carpal arthrodesis in an Arabian Filly. Veterinary Surgery, v.35, p.618-625, 2006. Available from: $<$ https:// www.ncbi.nlm.nih.gov/pubmed/17026546>. Accessed: Oct. 12, 2016. doi: 10.1111/j.1532-950x.2006.00199.x. 


\section{Erratum}

In the article "Didatic approach of ultrasonographic examination for evaluation of the carpal joint in horses“", published in Ciência Rural, volume 47, number 12, DOI http://dx.doi.org/10.1590/0103-8478cr20161017.

This image was published in figure 2:
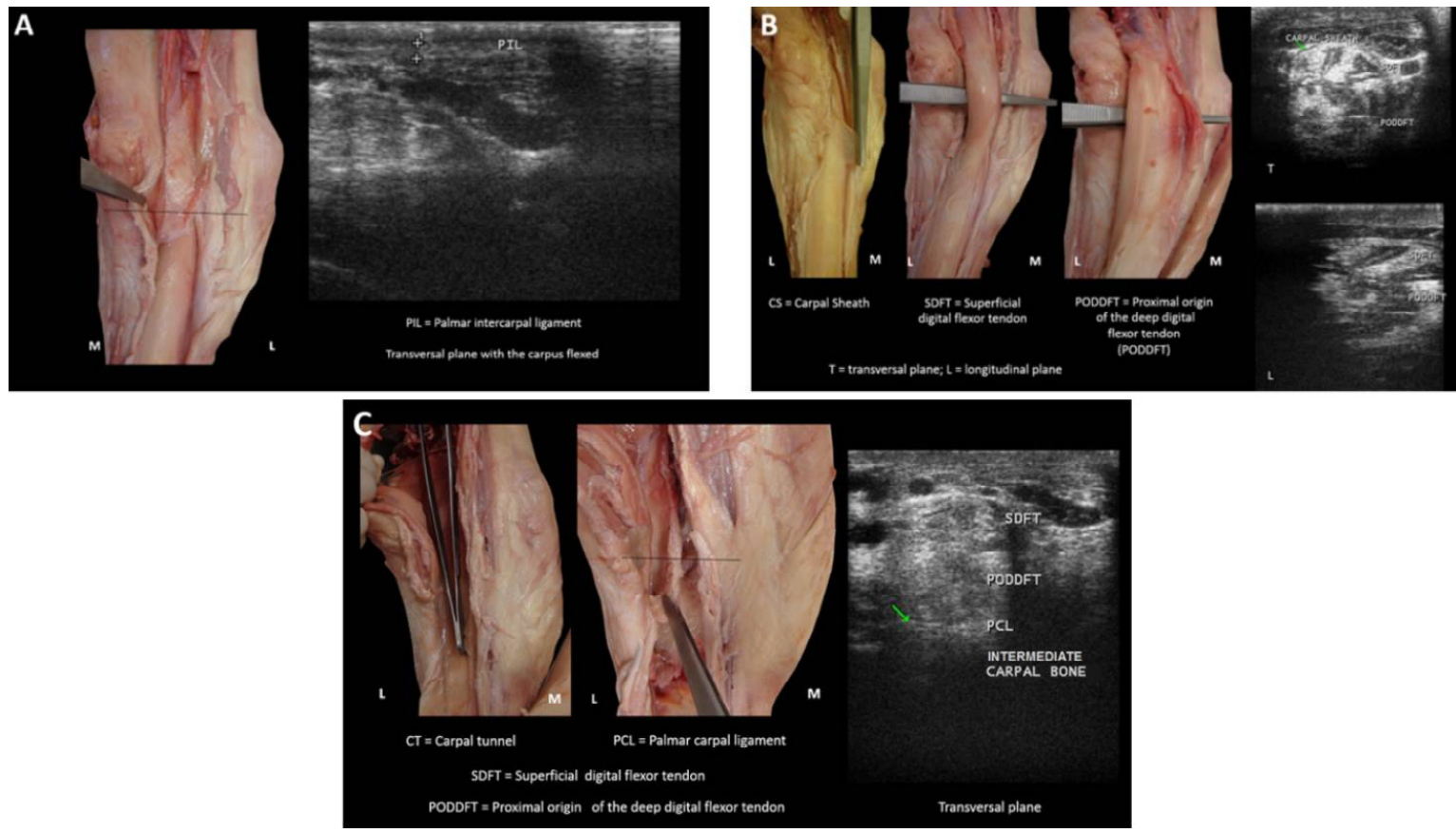

The correct image of figure 2 is:
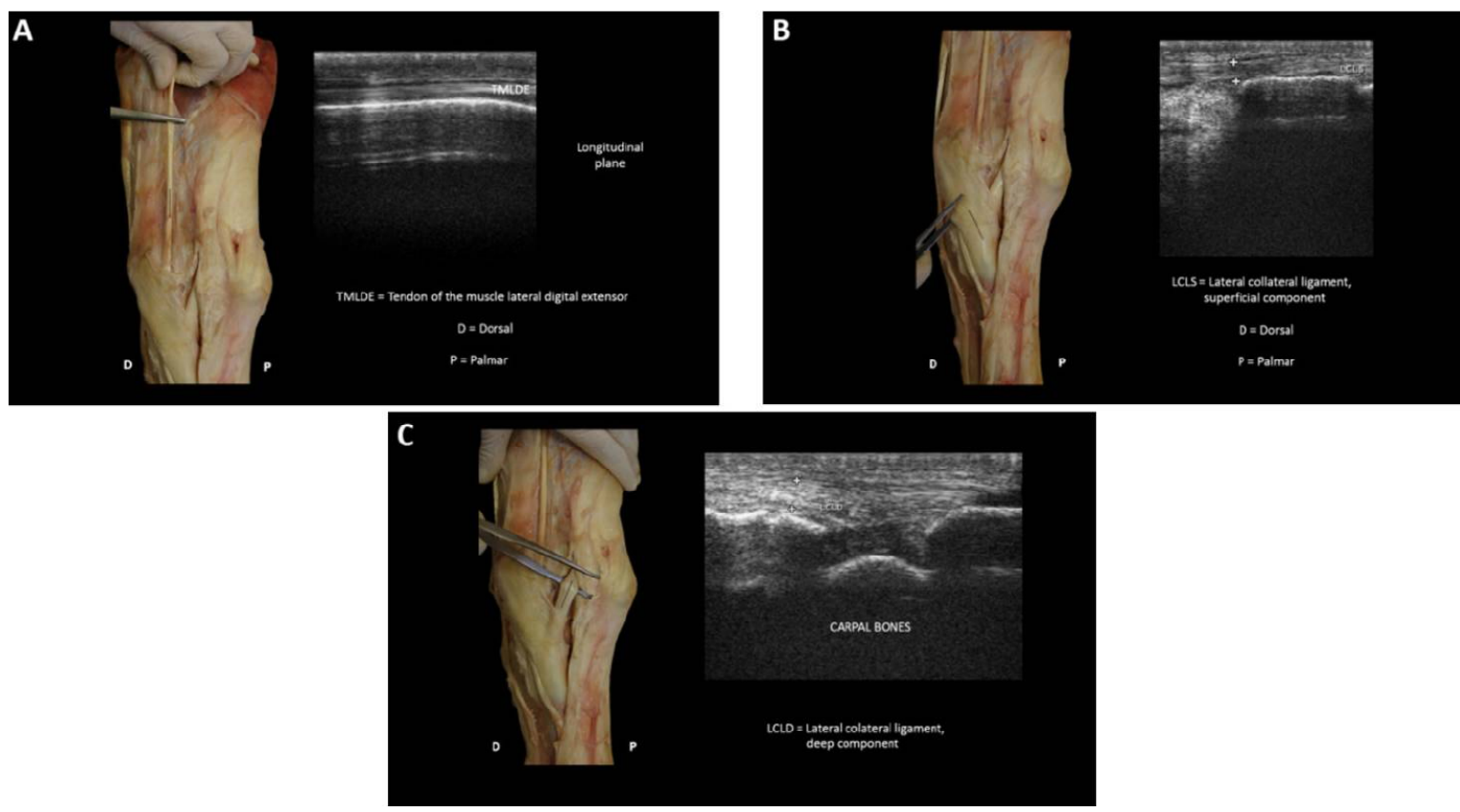